\title{
STRATEGI KOMUNIKASI PEMBERDAYAAN MASYARAKAT DESA (Implementasi Program PKKP Dinas Pemuda, Olahraga dan Pariwisata Jawa Tengah Tahun 2018 di Desa Tambakselo, Grobogan)
}

\author{
Ali Damsuki \\ Pascasarjana UIN Walisongo Semarang \\ Jl. Walisongo No.3-5 Tambak Aji, Ngaliyan-Semarang \\ Email : ali.damsuki@gmail
}

\begin{abstract}
This study discusses the communication strategies of PKKP 2018 participants (Youth Care and Leadership Program) of the Department of Youth and Sports of Central Java Province in empowering rural communities, especially for youth who are included in the youth group and PKK in Tambakselo village, Grobogan, Central Java. village. Interest in what communication strategies are made by 2018 PKKP participants so that the community empowerment program in the Tambakselo village in Central Java Grobogan district can be established, realized and even transforms the community towards a brighter future. The purpose of this study was to obtain an overview of the communication strategies carried out by PKKP 2018 participants. The empowerment of village communities was decided on for Youth Organizations and PKK, which mostly consisted of young people and girls who had the enthusiasm to develop the village. Starting from the field of small and medium enterprises to the field of education that will be promoted in the village. The research approach used in this study is to use the case study method as one of the qualitative traditions. From the research it is known that community empowerment activities in Tambakselo, Grobogan district, Central Java have been carried out and have succeeded in changing the level of community awareness in developing their own regions through the PKKP program and other village programs.
\end{abstract}

Keywords: Strategy, Communication, Empowerment of Village Communities 


\begin{abstract}
Abstrak
Penelitian ini membahas tentang strategi komunikasi peserta PKKP 2018 (Program Kepedulian dan Kepeloporan Pemuda) Dinas Pemuda dan Olahraga Provinsi Jawa Tengah dalam pemberdayaan masyarakat desa khusunya bagi pemuda yang masuk dalam kelompok karang taruna dan PKK di desa Tambakselo kabupaten Grobogan Jawa Tengah menjadi salah upaya untuk memajukan desa. Ketertarikan akan strategi komunikasi seperti apa yang dibuat oleh peserta PKKP 2018 sehingga program pemberdayaan masyarakat desa Tambakselo kabupaten Grobogan Jawa Tengah ini dapat terjalin, terwujud dan bahkan merubah masyarakat menuju masa depan yang lebih cerah. Tujuan penelitian ini dilakukan untuk memperoleh gambaran mengenai strategi komunikasi yang dilakukan oleh peserta PKKP 2018. Pemberdayaan masyarakat desa dikususkan lebih bagi Karang Taruna dan PKK yang sebagian besar terdiri dari pemuda dan pemudi yang memiliki semangat untuk membangun desa. Mulai dari bidang usaha kecil menengah hingga bidang pendidikan yang akan dimajukan di desa tersebut. Pendekatan poenelitian yang digunakan dalam penelitian ini adalah dengan menggunakan metode studi kasus sebagai salah satu tradisi kualitatif. Dari penelitian diketahui bahwa kegiatan pemberdayaan masyarakat di Tambakselo kabupaten Grobogan Jawa Tengah telah dilaksanakan dan berhasil mengubah tingkat kesadaran masyarakat dalam membangun daerahnya sendiri melalui program PKKP dan programprogram desa lainnya.
\end{abstract}

Kata kunci : Strategi, Komunikasi, Pemberdayaan Masyarakat Desa.

\section{A. PENDAHULUAN}

Pengembangan masyarakat sejatinya merupakan sebuah proses. Dalam mengevaluasi proyek pengembangan masyarakat, siapapun harus melihat proses, dan dalam merencanakan dan menerapkan program pengembangan masyarakat apapun senantiasa merupakan proses, bukan hasil, yang harus diberikan pertimbangan yang mendalam. Berkaitan dengan pengembangan masyarakat yang harus didasari oleh pengembangan personal dari masing-masing masyarakat, maka dari itu di mulai dengan pengembangan dari sisi masyarakat desa.

Menurut Soetrisno dalam Jacob (2000:185), pemberdayaan masyarakat atau empowerment adalah merubah kondisi program pembangunan yang sudah ada dengan cara memberi kesempatan pada kelompok orang miskin untuk merencanakan dan kemudian melaksanakan program pembangunan yang telah dipilihnya, serta memberikan kesempatan pada kelompok orang miskin untuk mengelola dana pembangunan dengan baik yang berasal daripemerintah maupun pihak lain.

\section{Program Kepedulian dan Kepeloporan} Pemuda merupakan salah satu program unggulan Dinas Kepemudaan, Olahraga dan Pariwisata Provinsi Jawa Tengah. PKKP ini menjadi program unggulan yang dikembangkan dengan tujuan mengakselerasikan pembangunan melaui peran kepeloporan pemuda dalam berbagai aktivitas kepemudaan. Aktivitas tersebut secara langsung harus berpengaruh terhadap dinamisasi kehidupan pemuda desa, potensi sumber daya kepemudaan, dan sekaligus meningkatkan kesejahteraan pemuda dan masyarakat desa. Dalam 
program PKKP ini juga diharapkan dapat meningkatkan peran dan kemampuan pemuda dalm bidang kepemimpinan, kemandirian, dan kepeloporan sesuai dengan UU No 40 Tahun 2009 (Disporapar, $2018: 1)$.

Program ini tentu menjadi salah satu program pembersayaan masyarakat desa melalui berbagai macam kegiatan seperti pelatihan wirausaha, pendidikan, dan pengelolaan dana bantuan pemerintah.

Beberapa program yang dijalankan oleh PKKP tentu memerlukan strategi komunikasi yang sesuai untuk memajukan dan memanfatkan potensi desa yang ada. Penyusunan strategi komunikasi pemberdayaan pada Karang Taruna dan PKK desa Tambakselo Grobogan di desa tersebut terlebih dahulu sebagai pedoman dalam pelaksanaan penyuluhan dan pembelajaran yang dijadikan sebagai program pemberdayaan masyarakat dalam program pendampingan wirausaha. Hal ini bertujuan untuk memaksimalkan program secara maksimal.

\section{B. METODE PENELITIAN}

Keseluruhan data yang dihimpun berasal dari data primer (main source of data) melalui wawancara 2 orang peserta PKKP 2018 yang ditempatkan di desa Tambakselo, Grobogan dan sumber sekunder (supportive data or information) berasal dari dokumentasi program observasi di lapangan. Teknik pengumpulan data informasi yang utama ditentukan melalui wawancara kepada2 orang peserta PKKP 2018.

Pengukuran data dilakuka dengan menggunakn model triangulasi dengan membandingkan hasil wawancara, observasi, dan dokumentasi yang ada. Dan adapun definisi operasional dalam penelitianini adalah menyangkut peranan fasilitator dalam membangun komunikasi untuk mensukseskan kegiatan-kegiatan PKKP 2018.

Beberapa peran yang seharusnya dapat dilakukan oleh fasilitator dalam melakukan pendampingan dimasyarakat, yaitu: motivator, pembawapesan, mediator, pendidik, peran teknis, mediator dan sebagai negosiator.

Pengamatan terlibatdilakukan pula terhadap rapat-rapat yang dilakukan oleh para relawan setiap sebulan sekali di desa. Pengamatan difokuskan kepada hal latar belakang tim fasilitator mensosialisasikan program dan bagaimana peserta PKKP 2018. Mempelajari dan melaksanakan program-program tersebut. Sementara itu data sekunder dihimpun dari informasi kepustakaan, baik dari buku teks, jurnal ilmiah, hasil penelitian, laporan dan dokumen Kesimpulan diperoleh dari justifikasi atas analisis terhadap temuan data penelitian. Meskipun demikian, jika setelah proses reduksi dan sajian data penelitian belum bias mengambil kesimpulan, peneliti perlu merevisi data yang dikumpulkan dan mengambil data baru jika dibutuhkan. Prose sini dapat digambarkan dalam bagan berikut: 


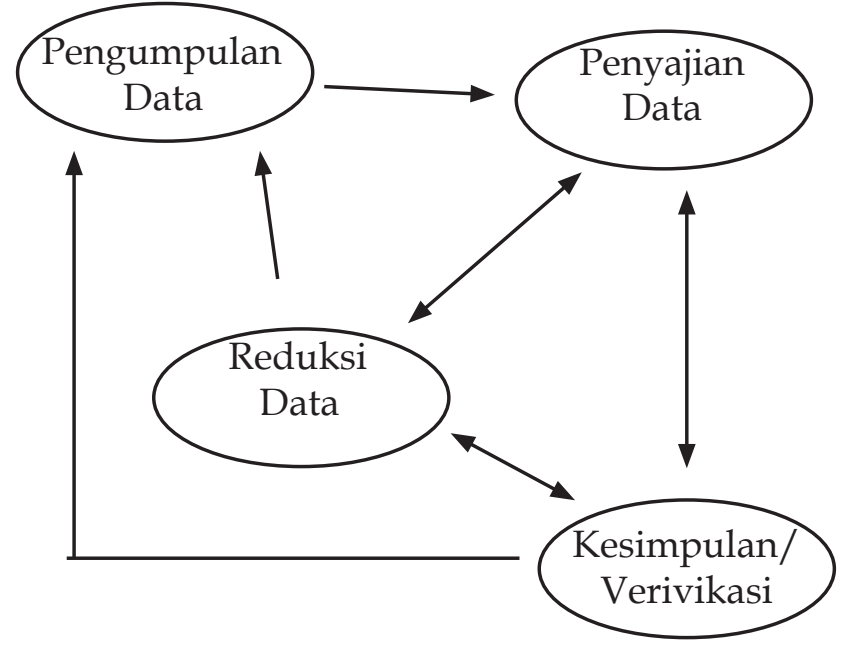

Gambar. 4. Model Interaksi

Sumber: Huberman\&Miles (1994) dalam

Denzin (2009:592)

Penelitian ini menggunakan metode studi kasus sebagai salah satu tradisi kualitatif. Metode kualitatif menurut Daymon dan Holloway (2008:23) digambarkan lebih menekankan kata-kata sebagai unit analisis, dibandingkan dengan angka.

\section{HASIL DAN PEMBAHASAN}

Strategi komunikasi yang dilakukan untuk peningkatan partisipasi masyarakat dalam pembangunan desa dimulai sejak peletakan dasar kemampuan analisis masyarakat melalui pendidikan dan pelatihan sehingga mereka mampu mengenali permasalahan dan potensi desa, serta manfaat dari pembangunan yang akan dilakukan Masyarakat juga dilibatkan dalam perencanan, pelaksanaan, dan evaluasi pembangunan desa, berdasarkan kemampuan masyarakat tersebut. Bila hal ini dilakukan maka pembangunan desa akan tercapai dengan efektif danefisien. Dalam konsep pembangunan desa, menurut Suyanto (2013: 13) strategi

60 | Jurnal An-Nida, Vol. 11, No. 1, Januari-Juni 2019 komunikasi sangat diperlukan dalam membentuk konsep kinerja yang bersifat sosialis dan humanis. Oleh sebab itu, halhal yang perlu diperhatikan diantaranya adanya sosialiasi. Sosialisai merupakan suatu konsep umum yang bisa dimaknakan sebagai sebuah proses di mana kita belajar melalui interaksi dengan orang lain, tentang cara berpikir, merasakan, dan bertindak, di mana kesemuanya itu merupakan hal-hal yang sangat penting dalam menghasilkan partisipasi sosial yang efektif. Sosialisasi merupakan proses yang terus terjadi selama hidup kita.

Program-program pemberdayan masyarakat desa oleh peserta PKKP 2018 Disporapar Jateng dibagi dalam beberapa kategori sebagai upaya klasifikasi dan strategi komunikasi dalam memetakan masyarakat desa. Dinataranya ada program pemberdayaan pemuda desa, baik dalam bidang organisasi sosial maupun dalam bidang UMKM desa.

1. Program pemberdayaan bidang organisasi sosial

Orang-orang yang melaksanakan tugasnya mewujudkan usaha perubahan sosial tersebut dinamakan agen perubahan, yang menurut Rogers dan Shomaker (1971), merupakan petugas professional yang mempengaruhi putusan inovasi kilen menurut arah yang diinginkan oleh lembaga perubahan. Usaha-usaha pembangunan suatu masyarakat selalu ditandai oleh adanya sejumlah orang yang memelopori, menggerakkan, dan menyebarluaskan proses perubahan tersebut.

Pemuda merupakan tonggak dalam pembanguna bangsa Indonesia. Banyak dari kalangan pemuda yang berhasil

ISSN : 2085-3521, E-ISSN : 2548-9054 
memerdekaan bangsa Indonesia. Oleh sebab itu, eksistensi pemuda dalam negeri sangatlah dibutuhkan dalam berbagai aspek kehidupan. Menurut Abdulah (1974: 6), pemuda adalah individu dengan karakter yang dinamis, bahkan bergejolak dan optimis namun belum memiliki pengendalian emosi yang stabil. Oleh sebab itu pemuda harus menjadi bagian dari organisasi sosial desa.

Menurut Handajaningrat (1983: 45), organisasi diartikan sebagai "sarana atau alat untuk mencapai tujuan. Oleh karena itu dikatakan organisai adalah wadah kegiatan dari pada orang-orang yang bekerja sama dalam mencapai tujuan". Organisasi ini sudah dibentuk susunan dan prosedur kerja yang jelas biasanya ditandai dengan ditunjuknya seorang pemimpin dalam organisasi tersebut.

Sedangkan kondisi pemuda yang ada di Desa Tambakselo merupakan pemuda yang dapat dikategorikan dapat diperhitungkan eksistensinya. Hal ini ada beberapa bentuk organisasi pemuda yang baru saja bangkit dari kevakuman yang sangat lama. Karang Taruna “Tunas Muda" menjadi salah satu bentuk eksistensi yang akan dikembangkan dalam proses pembangunan dalam berbagai aspek kegaiatan kepemudaan.

Berbagai macam kegiatan seperti Jalan Sehat bersama, Perlombaan antar dusun; sepak bola, volly, pemuda pelopor, dan lain sebagainya menjadi salah satu kegiatan yang dapat menjadikan eksistensi pemuda hidup kembali setelah beberapa tahun stagnan. Selain itu, ada juga pemuda yang memiliki jiwa wirausaha, pendidik, dan politis yang dapat dioptimalisasikan dalam berbagai kegiatan, sehingga menjadi salah satu kesatuan yang bermakna dan saling berkontribusi.

Eksistensi pemuda desa Tambakselo ini tidak hanya dalam ruang lingkup Karang Taruna “Tunas Muda”. Akan tetapi ada kelompok PKK yang selalu memberikan ruang kepada pemuda perempuan dan Ibu-ibu untuk menjali koordinasi yang sosialis antar warga di Desa Tambakselo, Kec. Wirosari Kab. Grobogan. Hal ini direaliasikaan dalam berbagai pertemuan, diantaranya ialah pertemuan bulanan yang dilaksanakan tanggal 25 setiap bulannya. Kegiatan ini tentu memberikan dampak yang positif dalam pengembangan dan pemberdayaan desa setempat.

Pendekatan sosial memalui bidang keorganisasian pemuda desa Tambakselo selain Karang Taruna “Tunas Muda” ada PKK Desa Tambakselo, Kec. Wirosari Kab. Grobogan menjadi salah satu pilar yang secara nyata menjadi pioner dalam pembanguna yang bersifat fisik maupun karakter. Seperti halnya program wirausaha pemuda sablon, konveksi dan ternak ikan lele, dan usaha-usaha lainnya. Potensi ini juga secara tidak langsung dapat menjadi poin yang sangat penting bagi pembangunan desa.

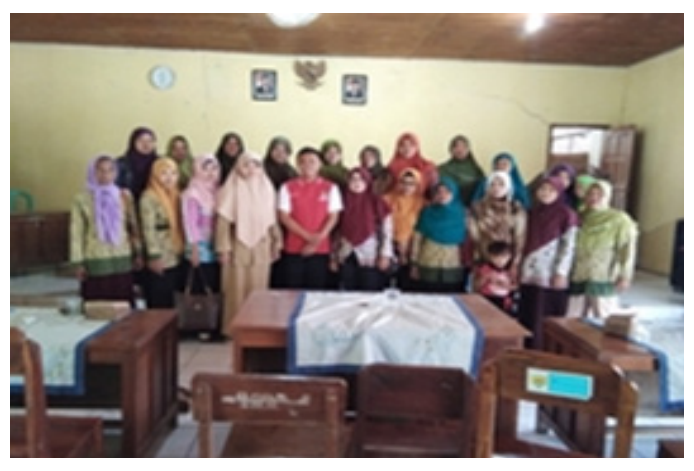

Gambar 2. Sosialisasi dengan Karang Taruna dan PKK

Jurnal An-Nida, Vol. 11, No. 1, Januari-Juni 2019 
2. Program Pendekatan Sosial melalui Usaha UKM Desa Tambakselo

Winarno ( 2011: 8) dalam buku Pengantar Kewiraswastaan Kerangka Dasar Memasuki Dunia Bisnis mengungkapkan definisi kewirausahaan sebagai proses penciptaan sesuatu yang berbeda nilainya dengan menggunakan usaha dan waktu yang diperlukan, memikul risiko finansial, psikologi, dan sosial yang menyertainya, serta menerima balas jasa finansial dan kepuasan pribadi.

Kewirausahaan dalam pandangan Islam merupakan aspek kehidupan yang dikelompokkan ke dalam masalah mu'amalah, yaitu masalah yang berkenaan dengan hubungan yang bersifat horizontal antar manusia dan tetap akan dipertanggungjawabkan kelak di akhirat. Dalam surat An-Najm ayat 39-42 mengingatkan kepada manusia.

Artinya: "dan bahwa manusia hanya memperoleh apa yang telah diusahakannya, dan sesungguhnya usahanya itu kelak akan diperlihatkan (kepadanya), kemudian akan diberi balasan kepadanya dengan balasan yang paling sempurna, dan sesungguhnya kepada Tuhanmulah kesudahannya (segala seuatu)". (QS. An-Najm ayat 39-42) (Depag, 2015: 66).

Pendekatan sosial memalui survey Usaha UKM ini menjadi salah satu media yang dapat manfaatkan dalam menjalin kerja sama yang kuat. Survey UKM ini dapat menghasilkan pemetaan yang lebih spesifik terkait potensi desa yang ada.
Tabel. 1. Data Jumlah Usaha

Desa Tambakselo Kec. Wirosari, Kab. Groboganprogram PKKP DISPORAPAR Jawa Tengah 2018

\begin{tabular}{|c|c|c|c|}
\hline No. & Dusun & Pemilik Usaha & Jenis Usaha \\
\hline \multirow[t]{5}{*}{1} & \multirow[t]{5}{*}{ Jatisemen } & Wahyuningsih & Somay \\
\hline & & Siswanto & $\begin{array}{l}\text { Somay dan } \\
\text { Es Buah }\end{array}$ \\
\hline & & Suparmono & $\begin{array}{l}\text { Somay dan } \\
\text { Es Buah }\end{array}$ \\
\hline & & Lasmini & Pangsit \\
\hline & & Mutiani & $\begin{array}{l}\text { Tanaman } \\
\text { Cabe dan } \\
\text { lain2 }\end{array}$ \\
\hline \multirow[t]{3}{*}{2} & \multirow[t]{3}{*}{ Welahan } & Jayus & $\begin{array}{l}\text { Warning } \\
\text { Jagung }\end{array}$ \\
\hline & & Jadi & $\begin{array}{l}\text { Warning } \\
\text { Jagung }\end{array}$ \\
\hline & & Kasman & $\begin{array}{l}\text { Ternak } \\
\text { Ayam Jawa } \\
\text { Super }\end{array}$ \\
\hline \multirow[t]{5}{*}{3} & \multirow[t]{5}{*}{ Jatisari } & Ali Imron & $\begin{array}{l}\text { Ternak Lele, } \\
\text { Gurame, } \\
\text { Nila } \\
\text { (Kelompok } \\
\text { Usaha) } \\
\end{array}$ \\
\hline & & Yusroni & Ikan Gurame \\
\hline & & Romadlon & Mebel \\
\hline & & Asmudi & Ternak Sapi \\
\hline & & Suyatno & Krupuk \\
\hline \multirow[t]{2}{*}{4} & \multirow[t]{2}{*}{ Tambakrejo } & Giarni & Kue Donat \\
\hline & & Ummu Fitria & Krupuk \\
\hline \multirow[t]{2}{*}{5} & \multirow[t]{2}{*}{ Wonorejo } & Kasipan & Krupuk \\
\hline & & Jamiatun & $\begin{array}{l}\text { Krupuk } \\
\text { Rambak }\end{array}$ \\
\hline 6 & Krajan & Tasmini & $\begin{array}{l}\text { Emping } \\
\text { Jagung dan } \\
\text { Ceriping }\end{array}$ \\
\hline \multirow[t]{4}{*}{7} & \multirow[t]{4}{*}{ Jati Tengah } & Sapto & $\begin{array}{l}\text { Emping } \\
\text { Jagung dan } \\
\text { Ceriping }\end{array}$ \\
\hline & & Suroyo & $\begin{array}{l}\text { Emping } \\
\text { Jagung dan } \\
\text { Ceriping }\end{array}$ \\
\hline & & Suwondo & $\begin{array}{l}\text { Emping } \\
\text { Jagung dan } \\
\text { Ceriping }\end{array}$ \\
\hline & & Sukendar & $\begin{array}{l}\text { Emping } \\
\text { Jagung dan } \\
\text { Ceriping }\end{array}$ \\
\hline
\end{tabular}




\begin{tabular}{|c|c|c|c|}
\hline & & Supriyanto & $\begin{array}{l}\text { Emping } \\
\text { Jagung dan } \\
\text { Ceriping } \\
\end{array}$ \\
\hline & & Sutrisno & $\begin{array}{l}\text { Emping } \\
\text { Jagung dan } \\
\text { Ceriping }\end{array}$ \\
\hline & & Ahmadi & $\begin{array}{l}\text { Emping } \\
\text { Jagung dan } \\
\text { Ceriping }\end{array}$ \\
\hline & & Harno & $\begin{array}{l}\text { Emping } \\
\text { Jagung dan } \\
\text { Ceriping }\end{array}$ \\
\hline & & Purwati & $\begin{array}{l}\text { Emping } \\
\text { Jagung dan } \\
\text { Ceriping }\end{array}$ \\
\hline & & Abdul Rosyid & $\begin{array}{l}\text { Emping } \\
\text { Jagung dan } \\
\text { Ceriping }\end{array}$ \\
\hline 8 & Bangsri & Moh. Hasyim & $\begin{array}{l}\text { Emping, } \\
\text { Warning, } \\
\text { dan kedelai }\end{array}$ \\
\hline
\end{tabular}

Daftar tersebut menunjukkan bahwa potensi pangan terbesar Desa Tambakselo didominasi oleh Jagung. Sehingga banyak pengusaha yang memanfaatkan Jagung untuk dibuat sebagaia makanan ringan seperti emping jagung dan warning jagung. Akan tetapi, konsisitersebut juga tidak menafikkan usaha yang lain pun dilakukan seperti halnya, kerupuk, kedelai, ternak lele, sapi, dan lain sebagainya.

Ada beberapa pelaku usaha yang peneliti survey berkaitan dengan usahanya, diantaranya sebagai berikut;

\section{Usaha Mandiri Tani}

Nama usaha Mandiri Tani, jenis usaha bibit tanaman cabe, terong, dan sayur mayor. Pemilik usaha Ibu Mutiani dengan alamat Dusun Jatisemen, Desa Tambakselo, Kec. Wirosari Kabupaten Grobogan.

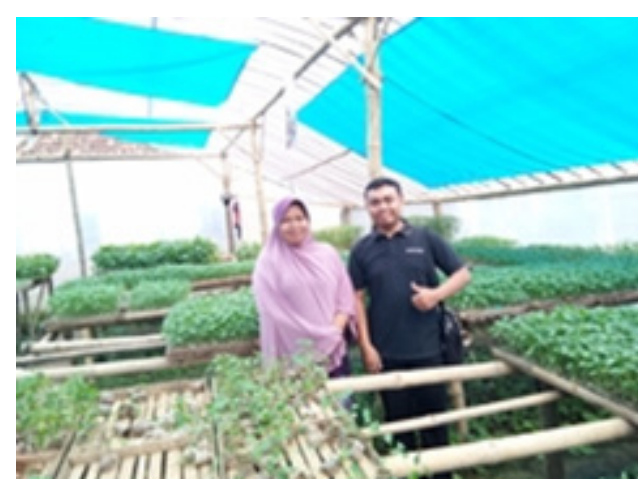

Gambar 3.

Foto Survey Usaha Mandiri Tani

2. Usaha Makanan Ringan

Nama usaha Lasmini Snack, jenis usaha Makanan Pangsit. Usaha ini terletak di Dusun Jatisemen, Desa Tambakselo Kab. Grobogan.

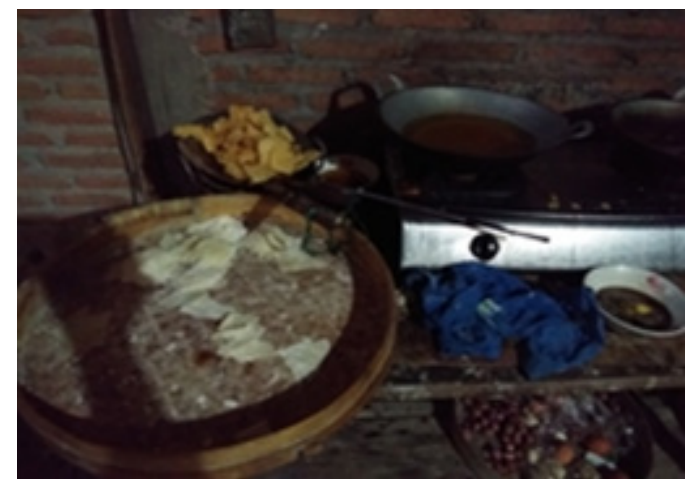

Gambar 4.

Foto Usaha Makanan Ringan

3. Usaha Ternak Ikan

Nama usaha Ternak Ikan, jenis usaha ikan lele dan gurami. Pemilik usaha ini Bapak Ali Imron dengan alamat Dusun Jatisari, Desa Tambakselo Kab. Grobogan 


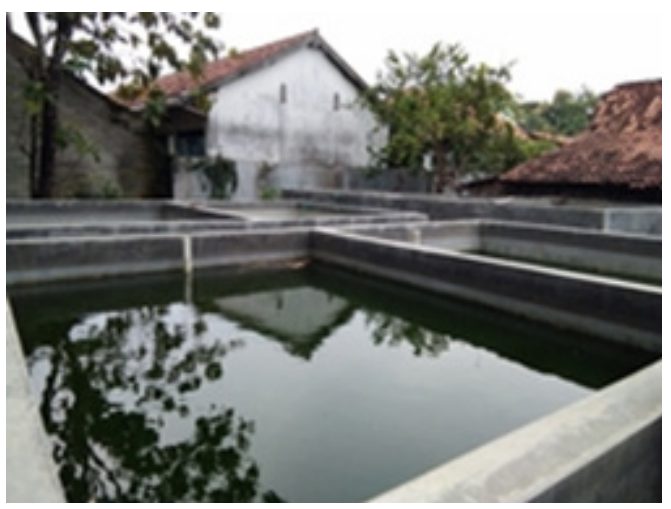

Gambar 5.

Foto Usaha Ternak Ikan

4. Usaha Marning dan Emping Jagung

Nama usaha Snack Crispy, jenis usaha Marning dan Emping Jagung. Pemilik usaha ini adalah Moch Hasyim dengan alamat Dusun Bangsri

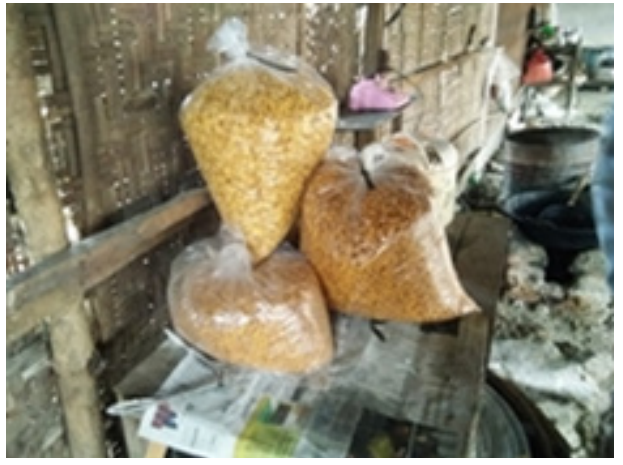

Gambar 6.

Foto Usaha Snack Crispy

5. Usaha Ternak Ayam Jago Super

Nama usaha Joper, usaha ini masuk jenis Ternak Ayam, dengan pemilik Kasman dengan alamat Dusun Welahan, Desa Tambakselo.

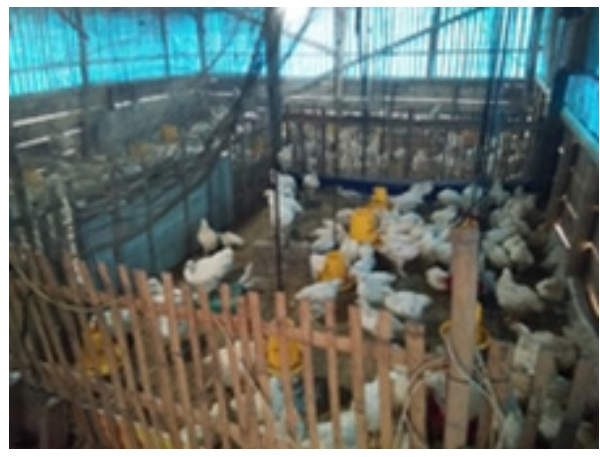

Gambar 7.

Usaha Ternak Ayam Jago Super

6. Usaha Kerajinan Akar Jati

Nama usaha Bakti Craft, jenis usaha ini masuk kategori Ukiran Jati dengan pemilik usaha Karjan yang bermukim di Dusun Ragem, Desa Tambakselo

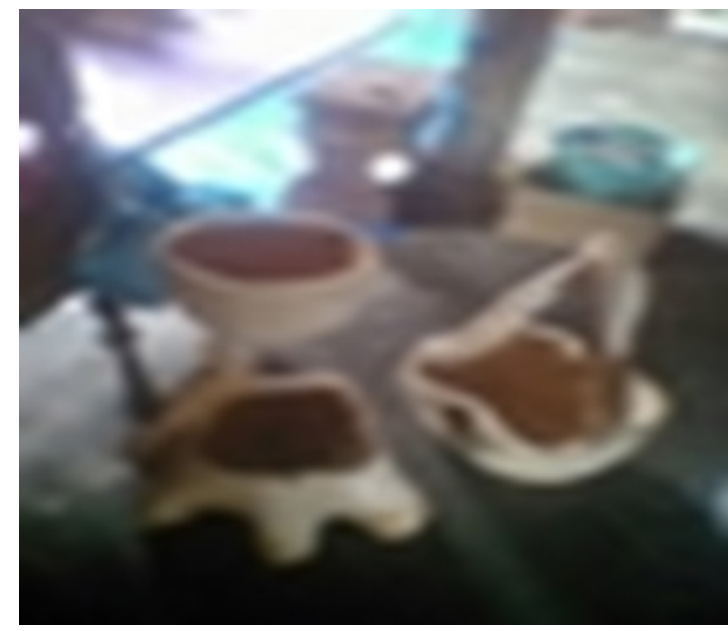

Gambar 8.

Kerajinan Akar Jati

Dari hasil potensi yang ada tentu program-program PKKP 2018 dapat dijalankan dengan metode pendekatan organisasi sosial dan ekonomi. Penelitian ini menunjukkan bahwa program PKKP 2018 memberikan kontribusi dalam bidang fasilitator dan mediator dalam proses strategi komunikasi dalam pemberdayaan masyarakat desa. 
3. Membangun Para Wirausaha Melalui Berbagai Macam Pelatihan

Desa Tambakselo merupakan desa yang memiliki banyak potensi bagi pengembangan usaha, kekayaan Sumber Daya Alam, jumlah penduduk, serta potensi pendukung lainnya menyebabkan pengusaha di Desa Tambakselo sangat antusias untuk memulai dan mengembangkan usaha di desanya. Hal tersebut ditandai dengan munculnya banyak kreatifitas usaha terutama produk olahan makanan dan lainnya. Untuk meningkatkan kreatifitas tersebut tentunya diperlukan langkah nyata dari semua pihak untuk secara bersama-sama menyusun semangat, kekuatan, dan tindakan bersama agar dapat berpartisipasi aktif dalam membangun usaha di desa.

Usaha pengembangan tersebut dapat diaplikasikan dalam bentuk diantaranya, a. Seminar sehari untuk mengubah cara berfikir sekaligus memupuk motivasi dengan membuka wawasan masyarakat desa Tambakselo, kerja sama dengan pihak-pihak terkait, b. Pelatihan selama tiga hari untuk memberikan pengathuan sekaligus praktek membuat olahan makanan atau membuat produk jadi. Hal tersebut dimaksudkan agar masyaraka desa Tambakselo memiliki pengalaman secara praktis, c. Pendampingan, hal ini dimaksudkan untuk menjaga semangat agar tetap tinggi, sekaligus memberikan bimbingan dan meningkatkan kemampuan dalam mengatasi tantangan yang dihadapi sewaktu mempersiapkan dan memulai usaha. Program ini menitikberatkan kepada masyarakat desa Tambakselo, Wirosari, Grobogan agar mampu menjadi wirausaha dengan memanfaatkan SDA yang ada di desa.

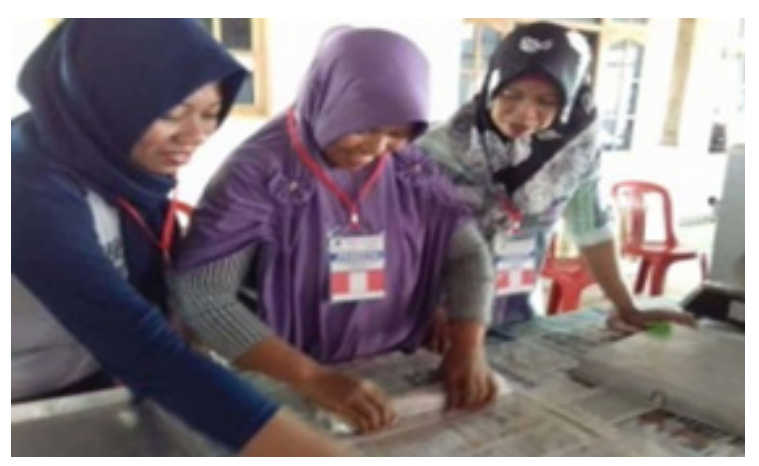

Gambar 9.

Pelatihan Olahan Makanan Kerjasama

Dinas Koprasi

4. Program Pendekatan Sosial dalam Bidang Pendidikan TK Kartini Tambakselo

Pendidikan Menurut Djumarsih (2004: 22) merupakan usaha manusia untuk menumbuhkan dan mengembangkan potensi-potensi pembawaan, baik jasmani maupun rohani sesuai dengan nilai-nilai yang ada dalam masyarkat dan kebudayaan. oleh sebeb itu, pendidikan juga merupakan usaha sadar dalam melakukan kegiatan belajar_mengajar dan proses pembelajaran dalam memahami suatu hal. Hal tersebut baik dilakukan secara formal maupun non-formal. Pengembangkan kemampuan intelektual, spiritual, maupun skill oleh peserta didik menjadi faktor utama. Untuk menjadikan pendidikan lebih memiliki signifikansi. Karena, bahwasanya pendidikan akan menentukan Legal-Formal kedepannya untuk dijadikan sebagai tumpuan dalam menjalani kehidupan bermasyarakat maupun berkeluarga.

Disamping itu, pendidikan berbasis agama, menjadi sangat penting. Karena, 
itu akan menentukan prilaku manusia dalam bersosial. Ketika pendidikan disandingkan dengan agama, yang kemudian diimplementasikan secara sosialis. Maka terbentuklah kecerdasan yang diiringi dengan akhlakul karimah. Bentuk implementasi pendidikan tersebut tidak hanya menitik kepada ruang lingkup pendidikan formal, tetapi juga lingkup pendidikan non-formal.

Pendekatan sosial memalui bidang pendidikan ini menjadi salah satu media yang dapat manfaatkan dalam menjalin kerja sama yang kuat. Selain dapat mencerdasakan anak juga dapat memberikan bantuan sosial yang nyata tanpa tanda jasa. Sehingga potensi desa tidak hanya berupa materi, akan tetapi perlunya pendidikan juga menjadi poin yang sangat penting bagi pembangunan desa.

TK Kartini Tambakselo merupakan sakah satu media pembelajaran yang terletak di Dusun Krajan, Desa Tambakselo, Kec. Wirosari Kab. Grobogan. TK Kartini diasuh oleh Bu. Purnamawati selaku Kepala Sekolah dan Bu Sulis Nurjasih selaku Guru pembimbing

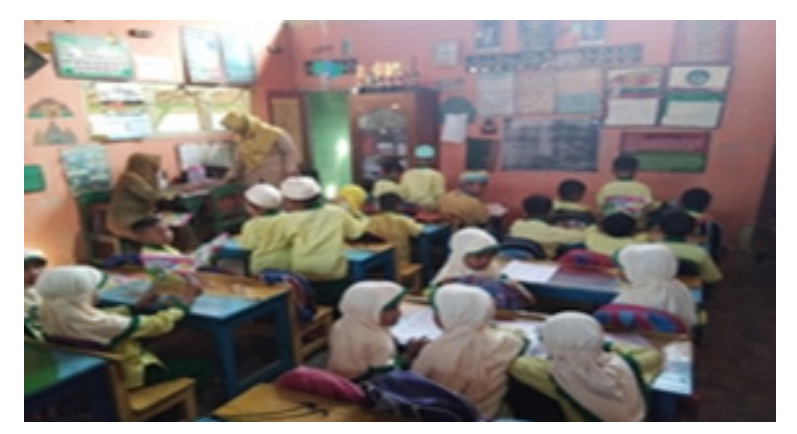

Gambar 12.

Kegiatan TK Kartini Tambakselo

\section{SIMPULAN}

Strategi komunikasi dalam pemberdayaan masyarakar desa yang dipelopori oleh peserta pkkp 2018 menjadi media dalam membangun desa. Hasil penelitian ini menunjukan kontribusi nyata dan positif dalam pembanguna pemuda desa dalam berbagai bidang, baik sosial, ekonomi, maupun pendidikan. Program Kepeloporan dan Kepedulian Pemuda (PKKP 2018) menjadi salah satu program unggulan dari Dinas Pemuda, Olahraga, dan Pariwisata Jawa Tengah dengan menggandeng para pemuda Jawa Tengah untuk terjun dalammasyarakat dan bertugas sebagai fasilitator dan mendampingi para pelaku usaha atau UKM yang ada di desa di seluruh Jawa Tengah.

Para pemuda yang memilki semangat juang dalam pengabdian masyarakat menjadi pemuda terpilih untuk mempelopori para pemuda di desa-desa di Jawa Tengah. PKKP ini diselenggarakan oleh Disporapar Jawa Tengah untuk mengurangi tingkat pengangguran yang ada di Jawa Tengah. PKK 2018 ini juga bekerjasam dengan beberap kabupaten di seluruh Jawa Tengah. Salah satunya ialah kabupaten Grobogan.

Grobogan menjadi salah satu kabupaten terpilih dalam program PKKP Disporapar Jawa Tengah karena memiliki banyak sekali potensi SDA yang ada. "Grobogan Bersemi" menjadi tagline yang sesuai dengan kekayaan alamnya, yaitu sebagai daerah yang memiliki potensi palawijanya. Seperti halanya padi, jagung, kacang, dan lain sebagainya.

Desa Tambakselo merupakan salah satu desa tersebsar di kabupaten Grobogan. Desa Tambakselo, Wirosari merupakan salah satu wilayah desa di Indonesia 
dengan jumlah penduduk yang padat. Jumlah penduduk Desa Tambakselo akhir sampai akhir Desember 2014 berjumlah 10.061orang, laki-laki berjumlah 5093 orang dan perempuan berjumlah 4968 orang.

Desa Tambakselo memiliki mulai banyak pelaku usaha yang memanfaatkan SDA yang ada, diantaranya ada warning jagung, ceriping pisang, keripik tela, usaha ternak ikan, ternak sapi, dan lain sebagainya. Hal itu juga didukung dengan aktifnya organisasi pemuda desa seperti PKK, Karang Taruna "Tunas Muda", Kelompok Tani, dan lainsebagainy sebagai salah satu pendukung dalam pembangunan desa Tambakselo.

Para pemuda mencoba "bangun dari tidurnya" untuk mulai bergerak membangun denga dengan mendidirikan beberapa usaha di bawah naungan Karang Taruna “Tunas Muda”, seperti Ternak Lele, Konveksi, dan Sablon yang saat ini sudah mulai dibangun. Hal ini bertujuan untuk memanfaatkan dana serta para pemuda agar dapat difungsikan denagan seksama dan maksimal. Hal ini mempermudan para PKKP untuk memberikan dampingan secara baik, selain itu juga semoga kedepannya usaha tersebut dapat menjadi pioner bagi masyarakat lainnya di desa Tambakselo, Wirosari, Grobogan.

\section{DAFTAR PUSTAKA}

\section{Buku}

Abdullah, Taufik. (1974). Pemuda dan Perubahan Sosial. Jakarta : LP3ES

Abdurokhman. (2012). Pengembangan Potensi Desa, Widyaiswara pada Kantor Diklat Kabupaten Banyumas.

Daymon, Christine \& Immy Holloway. 2008. Metode-Metode Riset Kualitatif dalam Public Relations \& Marketing Communications. Yogyakarta: PT Bentang Pustaka.

Departemen Agama. (2015). Al-Qur'an Terjemah Al-Huda. Jakarta: CV. Cahaya Hati.

Denzin, Norman K \&Yvonna S. Lincoln. (2009). Handbook of Qualitative Research.Yogyakarta: Pustaka Pelajar.

Djumransjah. (2004). Filasafat Pendidikan. Malang: Bayumedia Publishing.

Handajaningrat, Soewarno. (1983). Pengantar Ilmu Administrasi dan Manajemen. Jakarta : Gunung Agung.

Ife, Jim \& Frank Tesoriero. (2008). Community Development: Alternatif Pengembangan Masyarakat di Era Globalisasi. Yogyakarta: Pustaka Pelajar.

Jacob. (2000). Membongkar Mitos Masyarakat Madani. Yogyakarta: Pustaka Pelajar

Suyanto, Joko. (2013). Gender dan Sosialisasi, Jakarta: Nobel Edumedia, 2013.

Winarno. (2011). Pengembangan Sikap Entrepreneurship dan Intrapreneurship. Jakarta: Indeks.

Quin, Bc \& H. Mintzberg (1991). The Strategy, Concept, Contents, Case, Second ed. New Jersey: Pretice Hall Inc. 
Rogers,E.M. dan Shomaker,F.F. (1971). Communication of Innovation. New York: The Free Press.

Sumodiningrat, Gunawan. (2001). Responsi Pemerintah Terhadap Kesenjangan Ekonomi. Jakarta: PT Cipta Visi Mandiri.

Uchjana, Onong. (2002). Dinamika Komunikasi. Bandung: PT. Remaja Rosdakarya.

\section{Jurnal ilmiah}

Effendi, Tadjuddin Noer. (2004). "Mobilitas Pekerja, Remitan dan Peluang Berusaha diPedesaan".(JSP) FisipolUGM,Vol.8,No. 2.

Pingkan Adhitiawati, dkk. (2016)."Jurnal Sosioteknologi : Pengembangan Potensi Lokal di Desa Penawangan sebagai Model Desa Vokasi dalam Pemberdayaan Masyarakat dan Peningkatan Ketahanan Nasional", Vol. 15, No. 1. Bandung : ITB

Wahyu Ishardino Satries. (2009). Jurnal : Peran Serta Pemuda dalam Pembangunan Masyarakat", Madani Edisi Mei/I.

\section{Dokumen resmi pemerintah}

Undang-undang Republik Indonesia. Undang-Undang Nomor 40 Tahun 2009 tentang kepemudaan

Undang-undang Republik Indonesia. Undang Undang nomor 06 Tahun 2014 tentang Desa

Undang-undang Republik Indonesia. Undang Undang nomor 06 pasal 04 Tahun 2014 tentang Pengaturan Desa

Buku Pedoman Umum Program PKKP Tahun 2018 Disporapar Jawa Tengah.
Dokumen Daftar Siswa TK Tambakselo Tahun Ajaran 2017-2018, Dusun Krajan, Desa Tambakselo, Kecamatan Wirosari, Kabupaten Grobogan

Monografi Desa Tambakselo, Kecamatan Wirosari, Kabupaten Grobogan, 2017 